\title{
Another Reason to Omit Induction Radiotherapy: Save It for Last
}

\author{
Çağatay Tezel, Serdar Evman, Talha Doğruyol \\ Department of Thoracic Surgery, Süreyyapaşa Chest Diseases and Throracic Surgery Training and Research Hospital, İstanbul, Turkey
}

To the Editor,

We read the article questioning the timing of radiotherapy in locally advanced lung cancer, recently published in your journal by Yalman (1) with great interest. We would like to make a few comments from a surgeon's point of view.

Patients who undergo curative resection of locally advanced carcinoma of the lung have a significant rate of local recurrence and death from cancer in the few years following surgery. Pre- and postoperative irradiation and chemotherapy in various combinations and schedules have been recommended to improve the clinical outcome of these patients.

The results from retrospective data and several phase II trials have suggested that the addition of neoadjuvant radiotherapy to chemotherapy could improve the outcome of operable stage III non-small cell lung carcinoma; however, none of the small-volumed randomized trials including the SAKK trial could demonstrate any advantage in event-free, progressionfree, or overall survival (2).

Studies have shown that the addition of radiotherapy to chemotherapy is followed by a high rate of complete resection, an encouraging rate of complete pathologic response, and high mediastinal clearance of $\mathrm{N} 2$ disease, all of which represent potential positive surrogates for survival. The Southwest Oncology Group (SWOG) conducted the largest multi-institutional trial $(\mathrm{n}=126)$ with a concurrent chemoradiotherapy strategy which yielded a higher percentage of pCRs $(21 \%$ vs $0 \%)$; however, the 3-year overall survival rates were similar after the procedure of surgery followed by induction treatment plus concurrent chest radiotherapy with 45 Gy (3).

However, the main imperfection of the presented papers was that none of them revealed that those radiation fields during neoadjuvant planning were unfortunately covering both the areas of the main tumor and the mediastinal areas (Figure 1), even though the tumors were probably T2 or T3 tumors which were likely to be anatomically resectable. Therefore, according to our point of view, the tumor itself does not need to be irradiated as it can be completely resected after neoadjuvant chemotherapy. Every effort is being given on a patient basis or as personalized oncological treatment protocols, knowing that none of these locally advanced malignancy cases are the same and do behave differently.

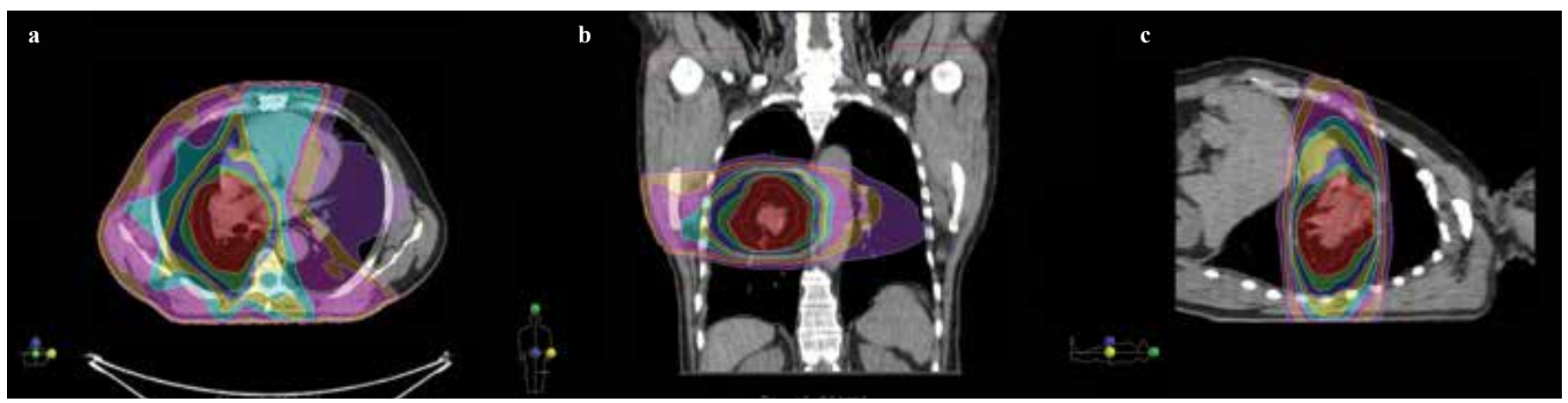

FIG. 1. a-c. An induction treatment graph for a patient with right upper lobe tumor and metastatic right lower mediastinal lymph node (\#4R). Extra fields with no need for irradiation that will further be removed by surgery are shown. Axial image (a), coronal image (b), sagittal image (c)

Address for Correspondence: Dr. Talha Doğruyol, Department of Thoracic Surgery, Süreyyapaşa Chest Diseases and Throracşc Surgery Training and Research Hospital, İstanbul, Turkey

Phone: +902164214200

Received: 8 June 2016 Accepted: 2 August 2016 • DOI: 10.5152/balkanmedj.2016.160898

Available at www.balkanmedicaljournal.org

Cite this article as:

Tezel Ç, Evman S, Doğruyol T. Another reason to omit induction radiotherapy: save it for last. Balkan Med J 2016;33:714-6. 
By saving the radiation for the postoperative period, patients might benefit more from radiotherapy due to a more precise and smaller area which necessitates being irradiated.

Therefore, in our opinion, the future role of radiotherapy will be to preserve the lethal weapon for the final stage, after minimizing the area by the surgery.

We would like to thank and congratulate the authors once again for this educative study.

Kind regards.

Ethics Committee Approval: N/A.

Informed Consent: N/A.

Peer-review: Externally peer-reviewed.

Author contributions: Concept - Ç.T.; Design - Ç.T.; Supervision - Ç.T., S.E.; Resource - T.D.; Materials - T.D.; Data Collection and/ or Processing - T.D.; Analysis and/or Interpretation - S.E.; Literature Search - Ç.T., T.D.; Writing - T.D.; Critical Reviews - Ç.T., S.E.

Conflict of Interest: No conflict of interest was declared by the authors.

Financial Disclosure: The authors declared that this study has received no financial support.

\section{REFERENCES}

1. Yalman D. Neoadjuvant radiotherapy/chemoradiotherapy in locally advanced non-small cell lung cancer. Balkan Med J 2015;32:1-7. [CrossRef]

2. Pless M, Stupp R, Ris HB, Stahel RA, Weder W, Thierstein S,et al. Neoadjuvant chemotherapy with or without preoperative irradiation in stage IIIA/N2 non-small cell lung cancer (NSCLC): A randomized phase III trial by the Swiss Group for Clinical Cancer Research (SAKK trial 16/00). J Clin Oncol 2013; 31

3. Albain KS, Rusch VW, Crowley JJ, Rice TW, Turrisi AT $3^{\text {rd }}$, Weick HK, et al. Concurrent cisplatin/etoposide plus chest radiotherapy followed by surgery for stages IIIA (N2) and IIIB non-small-cell lung cancer: mature results of Southwest Oncology Group phase II study 8805. J Clin Oncol 1995;13:1880-92.

\section{AUTHORS' REPLY}

Deniz Yalman

Department of Radiation Oncology, Ege University School of Medicine, İzmir, Turkey

To the Editor,

I thank Tezel et al. (1) for their letter. It was interesting to have comments from a thoracic surgeon's point of view.
At the beginning of their letter the authors stated that they read the article "questioning the timing of radiotherapy in locally advanced lung cancer". Actually, the article was not questioning the timing of radiotherapy; rather, it was a review article about the place of radiotherapy/chemoradiotherapy in the neoadjuvant treatment of locally advanced non-small-cell lung cancer (NSCLC). As mentioned by the authors the prognosis of these patients is poor, with high rates of local and distant failure. On the other hand, in a minority of selected patients, the outcome can be improved by a combination of neoadjuvant chemotherapy (CT), radiotherapy (RT), and surgery. In the neoadjuvant approach CT or RT can be used either alone or in combination depending on the performance of the patient.

One of the studies mentioned by the authors which did not demonstrate any survival advantage of adding neoadjuvant chemoradiotherapy (CRT) was the phase III trial by the Swiss Group (SAKK trial 16/00). The authors referred to the abstract of this trial presented at the 2013 ASCO Annual Meeting. The results of this trial were published last year in The Lancet (2). The trial randomized 232 patients to three cycles of neoadjuvant $\mathrm{CT}$ followed by accelerated concomitant boost RT (117 patients) or neoadjuvant CT alone (115 patients), with subsequent surgery for all patients. Median event-free survival was 12.8 months in the CRT group and 11.6 months in the CT group $(\mathrm{p}=0.67)$. Although not statistically significant, median overall survival was in favor of the CRT group (37.1 months vs 26.2 months). Complete response rates for the CRT and CT groups were $3 \%$ and $2 \%$, respectively, and partial response rates were $57 \%$ and $42 \%$, respectively. When induction strategies were compared, any objective response rate was $61 \%$ in the CRT group and $44 \%$ in the CT group, and this difference was significant $(\mathrm{p}=0.012)$. R0 resection rates $(91 \%$ vs $81 \%)$, nodal downstaging rates (64\% vs $53 \%$ ), and pathological complete remission rates ( $16 \%$ vs $12 \%$ ) were in favor of the CRT group. The primary predictor of survival in neoadjuvant CRT studies is nodal downstaging, but in the SAKK trial no data about the survival of patients with nodal downstaging were presented.

The other study mentioned by the authors was a phase II study conducted by the Southwest Oncology Group (SWOG 8805) (3). In this study there was also a difference in overall survival in patients with mediastinal downstaging (three-year overall survival rates of $44 \%$ and $18 \%$ for $\mathrm{pN} 0$ and $\mathrm{pN} 2$ diseases, respectively), and the positive results of this study led to the phase III North American Intergroup Trial 0139 (INT 0139). The subgroup analysis of INT 0139 clearly showed that the overall survival rates were significantly longer for patients with nodal downstaging (five-year survival rates were $41 \%, 24 \%$, and $8 \%$ for N0, N1-3, or unknown or no surgical resection, respectively; $\mathrm{p}<0.0001$ ) (4).

The authors also stated that if the tumor is anatomically resectable then the tumor itself does not need to be irradi- 
ated as it can be completely resected after neoadjuvant CT. However, according to oncological principles the primary source of nodal spread is the primary tumor; therefore, both the main tumor and the involved mediastinal nodes had to be covered in the radiotherapy portal. With current technology, morbidity of RT has significantly decreased. Recent studies applying high RT doses with modern technology in the neoadjuvant setting demonstrated the safety of resection after RT with high nodal clearance rates and encouraging long-term survival results. Neoadjuvant CRT trials consistently showed that mediastinal downstaging matters and this is best achieved by the combination of $\mathrm{CT}$ and RT.

I completely agree with the authors' opinion of personalized oncological treatment. Neoadjuvant treatment of locally advanced NSCLC either by CT or by CRT is one of the most challenging issues in the treatment of this disease. Every patient should be evaluated individually by a multidisciplinary team. There is no reason to omit RT in the neoadjuvant setting in appropriately selected patients.
Address for Correspondence: Deniz Yalman, Department of Radiation Oncology, Ege University School of Medicine, İzmir, Turkey

Phone: +905325705262 E-mail: yalman.deniz@gmail.com

\section{REFERENCES}

1. Tezel Ç, Evman S, Doğruyol T. Another reason to omit induction radiotherapy: save it for last. Balkan Med J 2016;33:714-6.

2. Pless M, Stupp R, Ris HB, Stahel RA, Weder W, Thierstein S, et al. Induction chemoradiation in stage IIIA/N2 non-small-cell lung cancer: a phase 3 randomised trial. Lancet 2015;386:104956. [CrossRef]

3. Albain KS, Rusch VW, Crowley JJ, Rice TW, Turrisi AT 3rd, Weick JK, et al. Concurrent cisplatin/etoposide plus chest radiotherapy followed by surgery for stagesIIIA (N2) and IIIB nonsmall cell lung cancer: mature results of Southwest Oncology Group phase II study 8805. J Clin Oncol 1995;13:1880-92.

4. Albain KS, Swann S, Rusch VW, Turrisi AT 3rd, Shepherd FA, Smith C, et al. Radiotherapy plus chemotherapy with or without surgical resection for stage III non-small-cell lung cancer: A phase III randomised controlled trial. Lancet 2009;374:379-86. [CrossRef] 